\title{
Financial advantage, outsourcing and FDI under wage uncertainty
}

\author{
E. Kwan Choi ${ }^{\mathrm{a}, \mathrm{b}, *}$, Jai-Young Choi ${ }^{\mathrm{c}}$ \\ a Iowa State University, United States \\ b City University of Hong Kong, Hong Kong \\ c Lamar University, United States
}

\section{A R T I C L E I N F O}

\section{Article history:}

Received 23 December 2011

Received in revised form 14 September

2012

Accepted 3 October 2012

\section{JEL classification:}

F1

Keywords:

Outsourcing

Foreign direct investment

\begin{abstract}
A B S T R A C T
This paper investigates outsourcing and foreign direct investment (FDI) decisions in North-South trade under conditions of wage uncertainty. The North has a financial advantage to raise capital, but the South has the advantage of low wages. If the expected outsourcing cost is lower than the in-house production cost, some outsourcing to a Southern firm is optimal. However, outsourcing to an FDI firm is superior to outsourcing to a Southern firm as well as in-house production. This finding is consistent with the rising foreign direct investment in China by Northern firms.
\end{abstract}

(c) 2012 Elsevier Inc. All rights reserved.

\section{Introduction}

Many industries in developed economies now outsource their production activities to developing countries. Outsourcing is by no means a recent invention. Due to lack of domestic recruits, Rome began to outsource military operations to hired mercenaries and non-Roman forces became auxilia. ${ }^{1}$ Since the 1990s, industrial outsourcing has been increasing at a dramatic pace to reduce high labor costs.

Research and development activities may occur in developed countries, but production processes often are shifted to China and India to take advantage of lower manufacturing costs. The era of

\footnotetext{
* Corresponding author at: Department of Economics, Iowa State University, Ames, IA 50010, United States. Tel.: +1 515294 5999; fax: +1 5152949913.

E-mail address: kchoi@iastate.edu (E.K. Choi).

${ }^{1}$ In $53 \mathrm{BC}$, Julius Caesar hired Teutonic mercenaries to carry out his conquest of Gaul. By the time of Constantine the Great (272-332 AD), the majority of the Roman troops were mercenaries.
} 
producing goods for domestic markets using domestic workers may be over. For instance, an electronic dictionary may be designed by Japanese producers for Japanese consumers, but the entire product may be produced in China where the labor cost is lower. ${ }^{2}$

Industrial outsourcing has received much attention in recent years. For example, Chao and Yu (1993) divided outsourcing or fragmentation of an industry into two stages. They analyzed the welfare effects of domestic content protection which limits outsourcing. Kohler (2004) developed a two-factor model with a dual representation of the technology of international fragmentation for an industry. He further investigated the role of outsourcing in the adjustment to a decline in the final output price of the multi-stage industry and the attendant factor price effect. Oladi (2004) studied interactive and retaliatory policies with regard to restrictions on foreign investment and labor migration. Long (2005) considered incomplete or partial outsourcing based on cheap foreign labor. He showed that due to the cost of the training needed to maintain quality, the head office may retain some production activity at home and outsource the rest. Görg and Hanley (2005) found some evidence of partial outsourcing in Irish Electric Industry. Jones (2005) showed that either immigration or outsourcing of a labor-intensive fragment of production may raise the real wage rate of national labor in a developed country, and pointed out how these two effects differ from each other. More recently, Batra and Beladi (2010a, 2010b) explored several major properties of international trade (including the welfare effect) by incorporating the factor-augmenting effect of outsourcing in the standard Heckscher-Ohlin model of general equilibrium. Despite the prolific and still growing body of literature, it is noteworthy that virtually no effort has been made to ascertain the role of uncertainty inherent to international outsourcing. $^{3}$

The purpose of this paper is to investigate the roles of financial cost and wages on outsourcing and foreign direct investment (FDI) decisions of multinational firms. Despite the uncertainty associated with outsourcing and FDI, cheap labor is the principal reason why Northern firms outsource production activities to China. In recent years, outsourcing to China, India and Vietnam has been hampered by frequent labor strikes that lead to higher wages. However, the outsourcing costs in these regions always have been lower than in-house costs in Europe or the United States. We assume that the North has a financial advantage in raising capital, but the South has the advantage of cheap labor. We investigate whether it is optimal for the Northern firm to outsource production to an independent Southern firm or to establish an FDI firm in the South.

This paper is organized as follows: Section 2 presents the basic model and its assumptions. Section 3 considers the decision to produce in-house or outsource to a Southern firm. Section 4 then compares outsourcing and FDI. Section 5 investigates the choice between in-house production and FDI in the South, and Section 6 offers concluding remarks.

\section{The model and its assumptions}

The Bosch Group is a technology-based multinational company including Robert Bosch $\mathrm{GmbH}$ and more than 300 subsidiaries in over 60 countries. Through its various subsidiaries, Bosch produces automotive parts, household appliances, and machine tools. For example, Bosch opened the first car service workshop in Shanghai in 1929, and sales of Bosch products in China reached $€ 2.2$ billion in 2008.

Consider a monopoly firm such as Bosch in the North which has been producing a good in-house for the domestic market. Due to the opening of trade with China, it is possible for the firm to outsource production to an independent foreign firm or establish a foreign subsidiary in China. The Northern firm

\footnotetext{
2 There is some confusion regarding the definition of the "outsourcer". In this paper, the outsourcing firm is called the outsourcer, and the firm that provides the outsourcing service is called the outsourcee. For example, infertile would-be mothers who would rent the uteri of young mothers (outsourcees) in developing countries are outsourcers.

${ }^{3}$ An exception is perhaps Choi (2007) which demonstrated the possibility of partial outsourcing under price uncertainty. In their recent paper, Oladi, Gilbert, and Beladi (2011) investigated the impact of FDI on real wages of skilled and unskilled labor in a three-sector general equilibrium model - however, their analysis also is devoid of uncertainty consideration. See also MacDermott (2007) who investigates the relationship between FDI and regional trade agreements and Kikuchi and Long (2010) for service offshoring.
} 
must determine whether to produce the good in-house, outsource it to a Southern firm, or outsource it to its FDI subsidiary in the South. We assume, as does Long (2005), constant returns to scale (CRS) technologies to ensure constant unit cost. Decreasing or increasing costs can obscure the nature of outsourcing and FDI decisions based on factor price differentials.

If production technologies are identical between the North and South, and factor prices are equalized between the two regions, there are no gains from outsourcing or FDI. Benefits from outsourcing or FDI exist only if production technologies or factor prices are different between countries. In this situation, unit costs of a product may be lower abroad. However, technologies are easily transferable between countries by multinational firms, and hence any technological gap can be bridged sooner or later. Thus, we assume that the Northern and the Southern producers have identical production technologies.

As for the cause of factor price differentials, we adopt the conventional assumption that international factor price differentials exist because factors are not perfectly mobile between countries. Specifically, we assume that labor is immobile between countries. Meanwhile, in recent decades, owing to improved transportation and communication technologies, capital has become increasingly more mobile between countries. Therefore, we assume that the multinational firm can raise its capital in the domestic market to set up a foreign subsidiary. However, due to a low credit rating, Southern firms can raise capital only in the South.

Let $w$ and $r$ respectively denote the Northern wage and rent, and the asterisk $\left(^{*}\right)$ indicate the corresponding Southern variables. As usual in the literature of economic development, we assume that the North has the financial advantage in raising capital $\left(r<r^{*}\right)$, and that the South has the advantage of a lower wage $\left(w>w^{*}\right)$. However, outsourcing to the South is hampered by frequent labor unrest which leads to a rise in wages. While China's wage is random, it always is lower than in Europe or the United States.

To analyze outsourcing and FDI decisions under wage uncertainty, we summarize the assumptions below:

(1) The North and the South use identical CRS technology to produce the output.

(2) The North has a financial advantage $\left(r<r^{*}\right)$, but the South has a low-wage advantage $\left(w>w^{*}\right)$. The factor price differentials exist due to the imperfect mobility of labor and capital between the two regions.

(3) The Northern firm can bring its capital input to its Southern subsidiary at the prevailing rate $r$, but the Southern firm can raise capital only in the South at the rate of $r^{*}$.

(4) Outsourcing to an independent Southern firm or its subsidiary is risky due to wage uncertainty.

\section{In-house production vs. outsourcing}

Assume that at first a monopoly firm (e.g., Bosch) was producing machine tools in-house to satisfy domestic consumers in the North. ${ }^{4}$ Due to the opening of trade with China, the firm now is free to outsource its production to an independent Southern firm or establish a foreign subsidiary in the South.

We first investigate whether the firm will outsource the product to an independent firm in the South. Let $X$ and $Y$ denote the quantity of in-house production and the quantity outsourced from an independent firm in the South, respectively. Let $p(Z)$ denote the inverse world demand function for the firm's total output, $Z=X+Y$, and $R(Z)=p(Z) Z$ be the revenue function. Note that marginal revenues are the same whether the output is produced in-house or outsourced, i.e.,

$$
R_{X} \equiv \frac{\partial p(X+Y)^{\bullet}(X+Y)}{\partial X}=p^{\prime}(X+Y)+p
$$

\footnotetext{
${ }^{4}$ Multinational firms like Bosch usually specialize in a few areas and produce a number of goods. For simplicity, the firm is assumed to produce only one good.
} 


$$
R_{Y} \equiv \frac{\partial p(X+Y)^{\bullet}(X+Y)}{\partial Y}=p^{\prime}(X+Y)+p
$$

and hence, $R_{X}=R_{Y}$ for all values of $X$ and $Y$. Thus, marginal revenue will be denoted by $m \equiv R_{X} \equiv R_{Y}$.

Unit production cost, $g(w, r, X)$, depends on factor prices and the output $X$. However, given the CRS production function, the unit cost is independent of output, i.e., $\partial g / \partial X=0$, and hence can be denoted by $g(w, r)$. If produced in-house, the unit production cost of the good is:

$$
g(w, r)=a_{L X}(w, r) w+a_{K X}(w, r) r,
$$

where $a_{i j}$ is the amount of $i$ th input per unit of $j$ th good, and $\partial a_{K X} / \partial w>0, \partial a_{L X} / \partial r>0, \partial a_{L X} / \partial r<0$, and $\partial a_{K X} / \partial r<0$. It is well known that the unit cost function $g(w, r)$ is concave in factor prices.

When the Northern firm outsources $Y$ units of output to a Southern outsourcee, it pays a random price $p^{*}$ per unit. Uncertainty in the outsourcing price originates in the labor market in the South, $p^{*}=g\left(w^{*}, r^{*}\right)$ where $r^{*}$ is fixed but $w^{*}$ is random. The Northern firm's problem is to choose $X$ and $Y$ to maximize expected utility of profit

$$
E U(\pi)=E U\left[p(Z)(X+Y)-g(w, r) X-p^{*} Y\right] .
$$

The first order condition is:

$$
\begin{aligned}
& E U^{\prime}(m-g) \equiv(m-g)^{\bullet} E U^{\prime}=0, \\
& E U^{\prime}\left(m-p^{*}\right) \equiv E U^{\prime}\left(m-E p^{*}\right)+\operatorname{Cov}\left(U^{\prime}, m-p^{*}\right)=0,
\end{aligned}
$$

where $U^{\prime}()>0,. U^{\prime \prime}()<$.0 for a risk-averse firm, and $\operatorname{Cov}\left(U^{\prime}, m-p^{*}\right)$ is covariance. For some in-house production to occur $(X>0), d E U / d X=(m(X)-g)^{\bullet} E U^{\prime}$ must be positive when evaluated at $X=0$, i.e., $m(0)>g$. This condition is satisfied because initially in-house production was profitable before considering outsourcing. Then Eq. (3) states that optimal in-house production $X$ occurs at a point where marginal revenue is equal to in-house unit cost, $m=g(w, r)$.

Next, note that $d U^{\prime} / d p^{*}=U^{\prime \prime}\left(\partial \pi / \partial p^{*}\right)=-U^{\prime \prime} Y>0$, and hence $\operatorname{Cov}\left(U^{\prime}, m-p^{*}\right)<0$, for $Y>0$. If the firm were risk neutral, its optimal outsourcing $Y$ would occur where $m=E p^{*}$. This implies that a risk-averse firm outsources less under price uncertainty than if the mean outsourcing price $E p^{*}$ were known.

Consider the case where the mean outsourcing price is equal to in-house unit cost, $E p^{*}=g(w, r)$ Then in (4), $m-E p^{*}=m-g=0$ and the left side of (4) is negative. In this case, no outsourcing occurs for the risk-averse firm because $\operatorname{Cov}\left(U^{\prime}, m-p^{*}\right)<0$. That is, for a risk-averse firm to engage in any outsourcing, the expected foreign price must be lower than in-house unit cost, $E p^{*}<g(w, r)$.

Next, assume that the expected outsourcing price is lower than the in-house unit cost, $E p^{*}<g(w, r)$. Then the Northern firm faces three possible options: (i) full in-house production $(Y=0, X>0)$, (ii) full outsourcing $(X=0, y>0)$, or (iii) partial outsourcing $(X>0, Y>0)$.

Case (i). Full in-house production occurs when the left side of (4) is negative at $Y=0$. That is

$$
\left.\frac{d E U}{d Y}\right|_{Y=0}=E\left\{U^{\prime}[p X-g X]\left(m-p^{*}\right)\right\}=U^{\prime} \bullet E\left(m-p^{*}\right)<0,
$$

where marginal revenue $m$ is evaluated at $(X, Y)=(X, 0)$. Even without price uncertainty, outsourcing requires that marginal revenue exceed marginal outsourcing cost $\left(m>p^{*}\right)$.

Cases (ii) and (iii). When the outsourcing price is uncertain, $m>E p^{*}$ is a necessary condition for outsourcing. If this condition holds, some outsourcing occurs and $E U^{\prime} m=E U^{\prime} p^{*}$. Inserting this condition into the left side of (3), we get $E U^{\prime}(m-g)=E U^{\prime}\left(p^{*}-g\right)$. When evaluated at $X=0$, this expression reduces to:

$$
\left.\frac{d E U}{d X}\right|_{X=0} \equiv E\left\{U^{\prime}\left[p Y-p^{*} Y\right]\left(p^{*}-g\right)\right\}=E\left(p^{*}-g\right)^{\bullet} E U+\operatorname{Cov}\left(U^{\prime}, p^{*}-g\right)
$$


If the expected outsourcing cost is lower than the in-house unit cost $\left(E p^{*}<g\right)$, the first term on the right hand side of (6) is negative. However, $d U^{\prime} / d p^{*}=-U^{\prime \prime} Y>0$, and $\operatorname{Cov}\left(U^{\prime}, p^{*}-g\right)>0$. Thus, either some or no in-house production can occur, i.e., $X \geq 0$. If the expected foreign price is sufficiently low $\left(E p^{*}-g<\right.$ $\left.\operatorname{Cov}\left(U^{\prime}, p^{*}-g\right) / E U^{\prime}\right)$, then $d E U / d X<0$ in (6), and in-house production stops and full outsourcing occurs. In particular, if the random outsourcing price is always lower than the in-house unit cost $\left(p^{*}<g\right)$, then $E\left\{U^{\prime}\left[p Y-p^{*} Y\right]\left(p^{*}-g\right)\right\}<0$ in (6). Thus, regardless of risk aversion, full outsourcing is optimal when the random outsourcing price $p^{*}$ is always less than in-house cost. ${ }^{5}$

These results are summarized here:

Proposition 1. Assume that outsourcing price $p^{*}$ is random. (i) If the expected outsourcing cost is equal to the in-house unit cost $\left(E p^{*}=g\right)$, no outsourcing is optimal. (ii) If the expected outsourcing cost is lower than the in-house unit cost $\left(E p^{*}<g\right)$, some outsourcing may occur. (iii) If the random outsourcing price $p^{*}$ is always less than the in-house unit cost $\left(p^{*}<g\right)$, full outsourcing is optimal, regardless of risk aversion.

The sufficient condition for full outsourcing, $p^{*}<g(w, r)$, is particularly relevant to those industries that outsource their products to low-wage countries such as China, India and Vietnam. Even though the outsourcing price in China is random, it is certain that the outsourcing cost is lower than the outsourcer's unit production cost. In this case, regardless of risk aversion, full outsourcing is optimal.

\section{Outsourcing vs. foreign direct investment}

If the expected price of the outsourced good from the South is less than the in-house unit production cost, the risk-averse Northern firm may choose one of the three options: full in-house production, full outsourcing, or partial outsourcing. However, the Northern firm still has another option. For example, Bosch may establish a subsidiary by foreign direct investment (FDI) in the South. That is, if in-house production is costly, the Northern firm may outsource the product to an independent firm or to its subsidiary in the South. The FDI firm is simply a foreign production plant. The foreign subsidiary also may sell some of its output to local firms or consumers in the South. However, for simplicity, we investigate only intra-industry FDI as in Baldwin and Ottaviano (2001), and assume that the Southern subsidiary does not sell its output to other markets. That is, the Southern FDI firm sells its output only to the Northern parent firm at cost.

Assume that each firm pays the opportunity cost of using capital input in its national market. Thus, the outsourcee in the South pays the Southern rent $r^{*}$ for its use of capital, but the subsidiary of the Northern firm pays the Northern rent $r$. Due to the low credit ratings of Southern firms, we assume $r<r^{*}$. Once the start-up capital is raised in the North, it is used to build a production plant in the South.

As before, the outsourcing price $p^{*}$ is a random variable, due to uncertainty in the Southern labor market. Let $Q$ denote the output produced by the FDI firm using Northern capital and Southern labor inputs. Let $G\left(w^{*}, r\right)$ denote the random cost function of the FDI firm using Southern labor. The Northern firm's problem is to choose $Y$ and $Q$ to maximize

$$
E U(\pi)=E U\left[p(Z)(Y+Q)-\left(p^{*} Y+G\left(w^{*}, r\right) Q\right)\right],
$$

where $Z=Y+Q$ is total output. Note that $R_{Y} \equiv \partial R / \partial Y=p^{\prime *}(Y+Q), R_{Q} \equiv \partial R / \partial Q=p^{\prime *}(Y+Q)+p$, and hence marginal revenue will be denoted by $m \equiv R_{Y} \equiv R_{Q}$.

We now show that optimal outsourcing to the Southern firm is zero. Suppose the contrary. Let $Y^{0}>0$ and $Q^{0}>0$ denote optimal outsourced output to an independent firm and an FDI firm, respectively, and let $\pi^{0}=\pi\left(Y^{0}, Q^{0}\right)$ be the associated profit. Then the firm can increase its

\footnotetext{
${ }^{5}$ However, marginal revenue for the first unit outsourced must exceed the expected price, $m>E p^{*}$. Evaluating the left-hand side of (4) at $X=0$ and $Y=0$, we get $d E U / d Y=E\left\{U^{\prime}\left[p(Z)(X+Y)-g(w, r) X-p^{*} Y\right]\left(m-p^{*}\right)\right\}=U^{\prime} E\left(m-p^{*}\right)$. If $m>E p^{*}$, then the expected utility is increasing in $Y$ at $Y=0$, and hence some outsourcing occurs. Thus, $m>E p^{*}$ is a necessary condition for some outsourcing to occur.
} 
profit by moving one unit from the Southern outsourcee to the FDI firm. Since the total output, $Z^{0}=\left(Y^{0}-1\right)+\left(Q^{0}+1\right)=Y^{0}+Q^{0}$, is unchanged, revenue remains the same. The firm's profit is:

$$
\pi\left(Y^{0}-1, Q^{0}+1\right) \equiv p\left(Y^{0}+Q^{0}\right)-\left(p^{*}\left(Y^{0}-1\right)+G\left(w^{*}, r\right)\left(Q^{0}+1\right)\right)=\pi^{0}+p^{*}-G\left(w^{*}, r\right) .
$$

Recall that the Northern subsidiary has a financial advantage $\left(r<r^{*}\right)$ but has access to the low-wage labor in the South. Thus, outsourcing to the FDI firm is always less costly

$$
p^{*}=a_{L Y}\left(w^{*}, r^{*}\right) w^{*}+a_{K Y}\left(w^{*}, r^{*}\right) r^{*}>a_{L Q}\left(w^{*}, r\right) w^{*}+a_{K Q}\left(w^{*}, r\right) r \equiv G\left(w^{*}, r\right) .
$$

Then for all $w^{*}$

$$
U\left(\pi^{0}\right) \equiv U\left[p\left(Y^{0}+Q^{0}\right)-\left(p^{*} Y^{0}+G\left(w^{*}, r\right) Q^{0}\right)\right]<U\left[\pi^{0}+p^{*}-G\left(w^{*}, r\right)\right],
$$

and $E U\left(\pi^{0}\right)<E U\left(\pi^{0}+p^{*}-G\left(w^{*}, r\right)\right)$. Thus, expected utility is maximized when all outsourced output $Y^{0}$ to the Southern firm is replaced by that to its FDI subsidiary. That is, optimal outsourcing to the Southern firm is zero.

From (7), the first order condition for optimal outsourcing to the FDI firm is: $E U^{\prime}\left(m-G\left(w^{*}, r\right)\right)=0$ for $Q>0$. Since random foreign price is no longer relevant, this condition reduces to:

$$
E U^{\prime}\left(m-G\left(w^{*}, r\right)\right)=E U^{\prime}(m-E G)+\operatorname{Cov}\left(U^{\prime}, m-G\right)=0 .
$$

Note that by Shephard's lemma, $\partial G / \partial w=L$. Moreover, $\partial L / \partial w<0$ and $d U^{\prime} / d w=U^{\prime \prime}\left(-G_{w^{*}}\right)>0$. Thus, $\operatorname{Cov}\left(U^{\prime}, m-G\right)<0$. This implies $m-E G>0$ That is, the firm outsources less output to its FDI firm than if the expected outsourcing cost $E G$ is known with certainty.

These results are summarized in the following proposition ${ }^{6}$ :

Proposition 2. Given assumptions (1)-(4), regardless of the random wage $w^{*}$, outsourcing to the FDI firm is superior to outsourcing to an independent Southern firm.

\section{In-house production vs. FDI under wage uncertainty}

Low wages are the principal reason for the Northern firm to establish FDI subsidiaries in China and other Asian countries. We assume that while the Southern wage is always lower, local firms in the South always pay higher rent than the Northern FDI firm, which raises capital in the North, i.e., $w>w^{*}, r<r^{*}$. Due to capital immobility or low credit ratings, the Southern firm pays a higher rent in the South. The previous proposition shows that the Northern firm chooses FDI over outsourcing to an independent Southern firm. We now consider in-house production versus FDI decisions.

Recall that the FDI subsidiary pays the Northern rent $(r)$ for its use of capital. The Northern parent firm's expected utility of profit in the presence of in-house production and FDI can be written as:

$$
E U(\pi)=E U\left[p(Z)(X+Q)-\left(g(w, r) X+G\left(w^{*}, r\right) Q\right)\right],
$$

where $Z=X+Q$ is total output. Recall that since capital is raised in the North, the producer pays the same Northern rent $(r)$, whether it produces in-house or outsources production to the FDI subsidiary. However, since it operates in the South, the FDI firm pays the Southern wage $\left(w^{*}\right)$, which is lower than the Northern wage for all random wage $w^{*}$. Thus, for all $w^{*}$,

$$
G\left(w^{*}, r\right)=a_{L 1}\left(w^{*}, r\right) w^{*}+a_{K 1}\left(w^{*}, r\right) r<a_{L 1}(w, r) w+a_{K 1}(w, r) r=g(w, r) .
$$

Thus, it is cheaper for the Northern firm to outsource production to its subsidiary than to produce in-house. Since the Southern wage is lower, the FDI firm has a cost advantage over the Northern firm's in-house production. For any in-house output $X$, the Northern firm can reduce its cost by outsourcing

\footnotetext{
${ }^{6}$ In this case where $w<w^{*}$ and $r=r^{*}$, the Northern firm should choose FDI over outsourcing to a Southern firm (despite the same factor prices it faces in both cases). In the principal-agent problem context here, outsourcing from its FDI subsidiary is less risky than outsourcing from an independent Southern firm. It is noteworthy that this superiority of FDI to outsourcing to a Southern firm continues to hold in the presence of perfectly mobile capital between the countries $\left(r \equiv r^{*}\right)$ due to the principal-agent reason.
} 
to its Southern subsidiary. Thus, the optimal in-house production is zero and full outsourcing to the FDI firm is optimal. It is noteworthy that this superiority of FDI to in-house production continues to hold in the presence of perfectly mobile capital between the countries $\left(r=r^{*}\right)$. Thus, the following proposition is immediately apparent.

Proposition 3. Assume that the Southern wage is uncertain but always lower than the Northern wage, $w<w^{*}$. Then the Northern firm chooses FDI over in-house production, and full outsourcing to the FDI subsidiary is optimal. This result continues to be valid when capital is perfectly mobile between the countries $\left(r=r^{*}\right)$ and the Northern firm's financial advantage disappears.

\section{Concluding remarks}

This paper investigates outsourcing and foreign direct investment (FDI) decisions in a North-South framework. Bosch, a company that produces machine tools, is used as an example. The price of outsourcing often is uncertain due to wage volatility. Despite wage uncertainty in the South, we assume that the South has a low-wage advantage over Northern firms, i.e., the random wage in China is always less than the wage in Europe or the United States. If the expected outsourcing price is equal to the in-house production cost, no outsourcing occurs. For some outsourcing to occur, the expected outsourcing price must be below the in-house cost.

We have shown that given identical technologies and the abundance of labor in China, partial or full outsourcing to an independent Southern firm can be superior to in-house production, but establishing an FDI subsidiary in the South is the dominant policy. Sometimes an FDI subsidiary can be established by buying a foreign producer. For example, in 1996 Bosch bought Skil, which was founded in 1924 by Edmond Michel who invented the portable circular saw.

Many European and American firms outsource labor-intensive products and establish subsidiaries to take advantage of cheap labor in China. This paper assumed that the FDI subsidiary sells its output only to the parent firm in the North. However, subsidiaries in China often sell outputs in the local markets. Thus, market extension is an additional reason for Northern firms to establish FDI subsidiaries in China. However, the majority of American firms are dwarfed by massive domestic firms in China. For example, Wal-Mart had 246 stores in China in March 2009, serving only a tiny portion of the Chinese population. For these firms to prosper in the South, the Northern firm must provide an essential ingredient at a lower cost than the local firms in the South. Further research is needed for FDI in this area.

\section{Acknowledgments}

The authors are indebted to two anonymous referees for their helpful comments. The usual caveats apply.

\section{References}

Baldwin, R. E., \& Ottaviano, G. I. P. (2001). Multiproduct multinationals and reciprocal FDI dumping. Journal of International Economics, 54, 429-448.

Batra, R., \& Beladi, H. (2010a). A simple two-sector model of outsourcing. Review of Development Economics, 14, 64-73.

Batra, R., \& Beladi, H. (2010b). Outsourcing and the Heckscher-Ohlin model. Review of International Economics, 18, $277-288$.

Chao, C.-c., \& Yu, E. (1993). Content protection, urban unemployment and welfare. Canadian Journal of Economics, 26 , 481-492.

Choi, K. E. (2007). To outsource or not to outsource in an integrated world. International Review of Economics and Finance, 16, 521-527.

Görg, H., \& Hanley, A. (2005). Labor demand effects of international outsourcing: Evidence from plant level data. International Review of Economics and Finance, 14, 365-376.

Jones, R. W. (2005). Immigration vs outsourcing: Effects on labor markets. International Review of Economics and Finance, 14, $105-114$.

Kikuchi, T., \& Long, N. V. (2010). A simple model of service offshoring with time zone differences. North American Journal of Economics and Finance, 21, 217-227.

Kohler, W. (2004). International outsourcing and factor prices with multistage production. Economic Journal, 114, $166-185$.

Long, N. V. (2005). Outsourcing and technology spillovers. International Review of Economics and Finance, 14, $297-304$. 
MacDermott, R. (2007). Regional trade agreement and foreign direct investment. North American Journal of Economics and Finance, 18, 107-116.

Oladi, R. (2004). Strategic quota on foreign investment and migration. Economic Theory, 24, 289-306.

Oladi, R., Gilbert, J., \& Beladi, H. (2011). Foreign direct investment, non-traded goods and real wages. Pacific Economic Review, $16,36-41$. 
lowa State University does not discriminate on the basis of race, color, age, religion, national origin, sexual orientation, gender identity, genetic information, sex, marital status, disability, or status as a U.S. veteran. Inquiries can be directed to the Director of Equal Opportunity and Compliance, 3280 Beardshear Hall, (515) 294-7612. 